\title{
PERANAN MODEL PEMBELAJARAN BERBASIS MULTIKULTURAL DALAM PEMBENTUKAN INTERAKSI SOSIAL
}

\author{
Nihayatun Hasanah ${ }^{1}$, Aris Suherman ${ }^{2}$, Yeti Nurizzati ${ }^{3}$ \\ Institut Agama Islam Negeri (IAIN) Syekh Nurjati Cirebon, Indonesia ${ }^{1,2,3}$ \\ NihayatunHasanah@syekhnurjati.ac.id, Arissuherman@syekhnurjati.ac.id \\ yeti@syekhnurjati.ac.id
}

\begin{abstract}
ABSTRAK
MTs Negeri 6 Cirebon Kabupaten Cirebon merupakan sekolah yang di dalamnya terdapat persoalan menyangkut interaksi sosial dengan latar belakang budaya yang berbeda. Dengan demikian, kurangnya interaksi sosial antarsiswa dan guru, kurangnya saling menghargai satu sama lain saat proses pembelajaran IPS,menjadikan pentingnya peranan model pembelajaran berbasis multikultural agar siswa dapat menghargai satu sama lain dan terjalinya interaksi sosial yang baik.Tujuan penelitian ini adalah: 1) Mengkaji tentang model pembelajaran berbasis multikultural di MTs Negeri 6 Cirebon Kabupaten Cirebon. 2)Mengkaji tentang peranan model pembelajaran berbasis dalam pembentukan interksi sosial di MTs Negeri 6 Cirebon Kabupaten Cirebon.3)Mengkaji tentang Faktor pendukung dan penghambat model pembelajaran berbasis multikultural terhadap pembentukan interaksi sosial pada mata pelajaran IPS siswa di MTs Negeri 6 Cirebon Kabupaten Cirebon.Pembelajaran berbasis multikultural adalah kebijakan dalam praktik pendidikan dalam mengakui, menerima dan menegaskan perbedaan dan persamaan manusia yang dikaitkan dengan gender, ras dan klas sosial

Jenis penelitian ini adalah penelitian kualitatif. Subyek penelitiannya adalah Guru Ilmu Pengetahuan Sosial, Waka Kurikulum dan siswa kelas VII MTs Negeri 6 Cirebon. Teknik yang digunakan dalam menentukan subjek penelitian adalah Triangulasi Sumber. Teknik pengumpulan data yang digunakan adalah observasi partisipan, wawancara, dan studi dokumentasi. Teknikanalisis data yang dilakukan adalah pengumpulan data, reduksi data, penyajiandata, dan penyimpulan data

Hasil penelitian ini menunjukan bahwa pada model pembelajaran berbasis multikultural dalam pembentukan interaksi sosial pada mata pelajaran IPS menggunankan metode yang menyesuaikan dengan materi yang disampaikan oleh guru. Peranan model pembelajaran berbasis multikultural dalam pembentukan interaksi sosial siswa yang baik di dalamnya terkandung nilai-nilai multikutural yaitu sikap toleransi, bertanggungjawab, bersahabat, kerjasama dan empati terhadap siswa. Faktor pendukung dan penghambat model pembelajaran berbasis multikuktural di MTs Negeri 6 Cirebon adalah faktor guru, peseta didik, sarana prasarana dan lingkungan. Dari faktor penghambat adalah guru, peserta didik, keluarga dan fasilitas (sarana prasarana).
\end{abstract}

Kata Kunci : Model Pembelajaran Berbasis Multikultural, Interaksi Sosial, IPS

Jurnal Edueksos Vol. IX, No. 1, Juni 2020

The journal of social and economics education 


\begin{abstract}
ABSTRACK
MTs Negeri 6 Cirebon Cirebon Regency is a school in which there are problems involving social interaction with different cultural backgrounds. Thus, the lack of social interaction between students and teachers, the lack of mutual respect for each other during the social studies learning process, makes the role of multicultural-based learning models important by instilling multicultural values so students can respect each other and the establishment of good social interaction.The objectives of this study are: 1) To examine multicultural-based learning models in MTs Negeri 6 Cirebon, Cirebon District. 2) Assessing the role of the learning based model in the formation of social interactions in MTs Negeri 6 Cirebon, Cirebon Regency. 3) Reviewing the supporting and inhibiting factors of multicultural-based learning models towards the formation of social interaction in students' social studies in MTs Negeri 6 Cirebon, Cirebon Regency. Multicultural based learning is a policy in the practice of education in recognizing, accepting and affirming human differences and similiarities associated with gender, race and social class.

This type of research is qualitative research. The research subjects were Social Sciences Teachers, Curriculum Waka and VII grade students of MTs Negeri 6 Cirebon. The technique used in determining the research subject is Source Triangulation. Data collection techniques used were participant observation, interviews, and documentation studies. Data analysis techniques used are data collection, data reduction, data presentation, and data conclusions.

The results of this study indicate that the multicultural-based learning model in the formation of social interaction in social studies subjects uses methods that adjust to the material presented to teacher. The role of multicultural-based learning models in the formation of good student social interactions contained in multicultural values namely tolerance, responsibility, friendship, cooperation and empathy for students. Supporting and inhibiting factors of multicultural-based learning models in the formation for grade VII students at MTs Negeri 6 Cirebon are the factors of teachers, student trainees, infrastructure and the environment. From the inhibiting factors are the teacher, students, families and facilities (infrastructure).
\end{abstract}

Keywords: Multicultural Based Learning Model, Social Interaction, Social Studies.

\title{
A. PENDAHULUAN
}

Undang-undang No 20 Tahun 2003 tentang sistem Pendidikan Nasional (UUSPN) bab II Pasal 3 tentang fungsi dan tujuan pendidikan bahwa "Pendidikan Nasional berfungsi untuk mengembangkan kemampuan dan membentuk watak serta peradaban bangsa yang bermartabat dalam rangka mencerdaskan kehidupan bangsa, bertujuan untuk berkembangnya potensi peserta didik agar menjadi manusia yang beriman dan bertakwa kepada Tuhan Yang Maha Esa dan berakhlak mulia, sehat, berilmu, cakap, kreatif, mandiri dan menjadi warga Negara yang demokratis serta bertanggung jawab. "Serta bab III pasal 4 yang menyatakan 
"Pendidikan diseleggarakan sebagai suatu proses pembudayaan dan pemberdayaan peserta didik yang berlangsung sepanjang hayat. "Dan bab IV pasal 5 yang menyatakan "Setiap warga Negara mempunyai hak yang sama untuk memperoleh pendidikan yang bermutu".

Pendidikan juga harus mampu menjadi wadah dalam memberikan penjelasan terhadap keberagaman yang ada di Indonesia serta membentuk sikap yang saling menghargai satu sama lain. Anak-anak itu memiliki karakter yang berbeda-beda bukan hanya dalam bakat atau pembawaanya akan tetapi terutama karena pengaruh dari lingkungan sosial yang lain-lain. Di sekolah ia akan memilih teman, kelompok yang ada pada suatu saat akan mempengaruhi tingkah lakunya. Selanjutnya, anak dipengaruhi oleh kepala sekolah dan guru-guru yang masing-masing mempunyai kepribadian sendiri-sendiri yang terbentuk atas suatu golongan yang dimana ia berasal dari orang-orang yang dipilihnya sebagai kelompok pergaulannya.

Peran aktif orang tua dan guru atau pendidik sangat dibutuhkan dalam mengarahkan anak-anak untuk menemukan jati dirinya dengan baik. Dengan demikian anak bisa mengekspresikan tanpa takut dan malu diejek, dihina, dan anak akan memiliki percaya tinggi apabila ada dorongan dan dukungan dari orang tua dan guru dalam interaksi sosial dengan teman-temannya.

Hal ini berkaitan dengan apa yang terjadi di kelas VII MTs Negeri 6 Cirebon Kabupaten Cirebon terlihat saat proses pembelajaran IPS, interaksi sosial adalah hubungan individu dengan individu, atau kelompok dengan ditandai komunikasi dan kontak sosial, realita yang terjadi di MTs Negeri 6 adalah kurangnya siswa saling berinteraksi sosial antarsiswa, guru dengan siswa, kurangnya saling menghargai satu sama lain antarsiswa dalam kegiatan belajar mengajar, serta kurangnya kerjasama antarsiswa yang baik pada saat tugas kelompok. Rasa toleransi antara satu sama lain merupakan sikap yang harus ditanamkan dalam diri siswa agar dapat menciptakan suasana yang kondusif di dalam kelas. Peneliti perlu mengkaji tentang model pembelajaran berbasis multikultural terhadap pembentukan interaksi sosial, dalam penerapannya menggunakan strategi-strategi saat pembelajaran berlangsung agar siswa bisa menghargai budaya dan bahasa dari teman-temannya walaupun memiliki latar belakang yang berbeda-beda, dengan adanya peranan model yang peneliti lakukan diharapkan dapat menciptakan nilai- 
nilai yang positif yaitu kerjasama, bersahabat, toleransi, bertanggungjawab, dan empati antarsiswa, guru dengan siswa di dalam lingkungan sekolah maupun lingkungan masyarakat.

Atas dasar masalah interaksi sosial dengan latar belakang budaya yang berbeda. Dengan demikian, kurangnya interaksi sosial antarsiswa dan guru, kurangnya saling menghargai satu sama lain saat proses pembelajaran IPS, menjadikan pentingnya Peranan model pembelajaran berbasis multikultural agar siswa dapat menghargai satu sama lain dan terjalinya interaksi sosial yang baik. Maka penulis meneliti lebih lanjut untuk mengambil judul "PERANAN MODEL PEMBELAJARAN BERBASIS MULTIKULTURAL DALAM PEMBENTUKAN INTERAKSI SOSIAL SISWA KELAS VII DI MTS NEGERI 6 KABUPATEN CIREBON"

\section{Model Pembelajaran Berbasis Multikultural}

Menurut Joyce dan Weil dalam Rusman (2011: 136) berpendapat bahwa model pembelajaran adalah suatu rencana atau pola yang dapat digunakan untuk membentuk kurikulum (rencana pembelajaran jangka panjang), merancang bahanbahan pembelajaran, dan membimbing pembelajaran di kelas atau yang lain. Model pembelajaran dapat dijadikan pola pilihan, artinya para guru boleh memilih model pembelajaran yang sesuai dan efesien untuk mencapai tujuan pendidikannya.

Model pembelajaran pada dasarnya merupakan bentuk pembelajaran yang tergambar dari awal sampai akhir yang disajikan secara khas oleh guru. Dengan kata lain, model pembelajaran merupakan bungkus atau bingkai dari penerapan suatu pendekatan, metode, dan teknik pembelajaran (Komalasari, 2010: 57).

Multikulturalisme berasal dari kata multi (banyak), kultur (budaya), dan isme (aliran atau paham). Secara hakiki, dalam kata itu terkandung pengakuan martabat manusia yang hidup dalam komunitasnya dengan kebudayaan masing-masing yang unik. Dengan demikian, setiap individu merasa dihargai sekaligus merasa bertanggung jawab untuk bertanggung jawab untuk hidup bersama komunitasnya. Pengingkaran suatu masyarakat terhadap kebutuhan untuk diakui merupakan akar dari segala ketimpangan dalam berbagai bidang kehidupan (Mahfudz, 2009: 75).

Secara etimologis multikulturalisme terdiri atas kata multi yang berarti plural, culture yang berarti kebudayaan, dan isme yang berarti aliran atau kepercayaan. 
Jadi multikulturalisme secara sederhana adalah paham atau aliran budaya yang plural (Rusdiana, 2015: 99).

Pembelajaran berbasis multikultural adalah kebijakan dalam praktik pendidikan dalam mengakui, menerima dan menegaskan perbedaan dan persamaan manusia yang dikaitkan dengan gender, ras dan kelas sosial (Ngalimun 2017: 117). Model pembelajaran ialah pola yang digunakan sebagai pedoman dalam merencanakan pembelajaran di kelas maupun tutorial. Menurut Arend model pembelajaran mengacu pada pendekatan yang akan digunakan, termasuk didalam tujuan-tujuan pembelajaran, tahap-tahap dalam kegiatan pembelajaran, dan pengelolaan kelas. Model pembelajaran dapat didefinisikan sebagai kerangka konseptual yang melukiskan prosedur sistematis dalam mengorganisasikan pengalaman belajar untuk mencapai tujuan belajar (Suprijono, 2010: 54-55).

Berhasil atau tidaknya pendidikan multikultural itu dapat dilihat ketika pendidikan itu mampu membentuk sikap peserta didik menjadi saling toleran, tidak berkonflik, tidak bermusuhan karena perbedaan suku, budaya, adat istiadat, bahasa, dan agama (Mahfudz, 2010: 217).

\section{Interaksi Sosial}

Menurut Gillin and gillin (1954) dalam Setiadi(2007: 91) menyatakan bahwa interaksi sosial adalah hubungan-hubungan antara orang-orang secara individual, antar kelompok orang, dan orang perorangan dengan kelompok. Interaksi sosial merupakan bentuk umum dari proses sosial dapat didefinisikan sebagai hubunganhubungan timbal balik antara individu dengan individu, kelompok dengan kelompok, serta antara individu dengan kelompok (Wulansari, 2009: 34).

Dengan demikian interaksi sosial merupakan hubungan-hubungan sosial yang dinamis mencakup hubungan antar orang-orang perorangan, antar kelompokkelompok manusia, maupun antar orang perorangan maupun kelompok dengan kelompok yang saling mempengaruhi satu sama lain dan mempunyai tujuan, berupa tindakan yang positif maupun negatif. (Sunarto, 2004: 43).Menurut Bonner dalam Gunawan (2010: 31) interaksi sosial merupakan hubungan antara dua orang atau lebih, sehingga kelakuan individu yang satu mempengaruhi, mengubah atau memperbaiki kelakuan individu yang lain, dan sebaliknya. 


\section{Mata Pelajaran IPS}

Menurut Trianto (2010: 171) menyatakan Ilmu Pengetahuan Sosial (IPS) merupakan integrasi dari berbagai cabang ilmu sosial seperti sosiologi, sejarah, geografi, ekonomi, politik, hukum dan budaya.Menurut Sapriya (2009: 19) Istilah ilmu pengetahuan sosial (IPS) merupakan nama mata pelajaran di tingkat sekolah dasar dan menengah atau nama program studi di perguruan tinggi identik dengan istilah "social studies".Menurut Mofet dalam (Suprayogi dkk, 2011:37) IPS memiliki makna sebagai pelajaran yang membantu manusia serta hubungannya dengan manusia lain dan lingkungannya.

\section{B. METODE PENELITIAN}

Penelitian ini menggunakan penelitian kualitatif dengan metode deskriptif yaitu penelitian yang lebih menekankan kepada penalaran, gambaran, analisis dan definisi suatu situasi tertentu, lebih banyak meneliti hal-hal yang berhubungan dengan kehidupan sehari-hari dan diperkuat oleh pendapat ahli. Menurut Creswell (2010: 4) penelitian kualitatif merupakan metode-metode untuk mengeksplorasi dan memahami makna yangoleh sejumlah individu atau sekelompok orang dianggap berasal dari masalah social atau kemanusiaan.

Penelitian kualitatif bersifat deskriptif dengan melakukan penggambaran secara mendalam tentang situasi yang diteliti sehingga dalam jenis penelitian ini peneliti tidak berusaha untuk menguji hipotesis seperti halnya dalam penelitian kuantitatif (Idrus, 2009: 24).

Tempat yang dijadikan dalam penelitian ini adalah di MTs Negeri 6 Cirebon Kabupaten Cirebon. Waktu penelitian selama kurang lebih 5 Bulan terhitung dari Januari 2019 s.d. Mei 2019. Yang menjadi subjek penelitian adalah Waka kurikulum, Guru IPS, dan Siswa kelas 7 MTs Negeri 6 Cirebon Kabupaten Cirebon. Dalam penelitian ini menggunakan 3 teknik pegumpulan data adalah Observasi partisipan, wawancara/ interview, dan studi dokumentasi. Adapun yangmenjadi instrumen pengumpulan datanya dilihat dari pedoman observasi dan pedoman wawancara.

Menurut sugiyono (2018: 185) menjelaskan bahwa uji keabsahan data dalam penelitian kualitatif meliputi uji credibility (validitas interval), transferability (validitas eksternal), dependability (reliabilitas), dan confirmability (obyektivitas). 
Dalam penelitian ini terdapat beberapa kriteria yang digunakan untuk memeriksa keabsahan data, antara lain derajat kepercayaan (triangulasi sumber, kecukupan reverensial, keteralihan dan kepastian). Peneliti menggunakan teknik analisis Miles \& Huberman, antara lain reduksi data, penyajian data, dan penarikan kesimpulan.

\section{HASIL DAN PEMBAHASAN}

Berdasarkan hasil observasi partisipan, wawancara dan studi dokumentasi di MTs Negeri 6 Cirebon Kabupaten Cirebon terdapat beberapa data yang diperoleh darisumber yang berbeda yang terkait dengan judul penelitian yaitu "Peranan model pemeblajaran berbasis multikultural dalam pembentukan interaksi sosial siswa kelas VII pada mata pelajaran IPS". Adapun hasil dari temuan penelitian yaitu sebagai berikut :

\section{Bagaimana Model Pembelajaran Berbasis Multikultural Di Mts Negeri 6 Cirebon Kabupaten Cirebon}

Dalam suatu pembelajaran tentu harus ditunjang dengan metode dan media yang baik untuk mencapai suatu keberhasilan siswa dalam proses belajar mengajar. Guru sebagai contoh kepada siswa yang memiliki wewenang dalam mengatur dan berjalannya proses pembelajaran berlangsung.Dalam menyampaikan materi yang disampaikan Guru IPS sangat berhati-hati selain menghindari ketidakpahaman siswa dalam menerima materi yang disampaikan, guru juga mencoba untuk lebih jelas dan mendalam menyampaikan nilai-nilai yang terkandung pada materi yang disampaikan, agar siswa dengan mudah menerima apa yang telah disampaikan dan siswa diharapkan bisa mengaplikasikan dalam kehidupan sehari-hari baik di sekolah maupun di lingkungan masyarakat sekitar supaya dapat mencapai hidup yang saling rukun dan harmonis.

Hal serupa juga disampaikan oleh Ahmad, S.Pd.I. selaku guru IPS bahwa dalam menerapkan model pembelajaran berbasis multikultural pada mata pelajaran IPS dari hasil wawancara 4 Mei 2019.

"Multikultural, hmm...ya ada beberapa guru yang melaksanakan pada mata pelajaran IPS dengan berbasis multikultural, kalau bapa sendiri sudah menerapkan dan biasanya siswa belajar di luar sekolah tugas secara kelompok (mengamati pembuatan tahu dari Distribusi, produksi sampai selesai) dengan begitu siswa dapat mengenal satu sama lain dan 
berinteraksi dengan baik walaupun dengan adanya perbedaan pendapat, dan bapa biasa memakai metode campuran tergantung mata pelajaran yang disampaikan tapi ceramah tidak akan lepas dari pelajaran yang bapa sampaikan".

Berdasarkan hasil observasi dan wawancara yang telah dilakukan, penerapan model pembelajaran berbasis multikultural di MTs Negeri 6 Cirebon Kabupaten Cirebon beberapa guru sudah menerapkan pada mata pelajaran IPS, ditandai dengan guru yang menggunakan model dan metode yang menarik pada saat pembelajaran berlangsung di dalam kelas untuk mencapai suatu tujuan pembelajaran yang diharapkan. Sebagaimana yang diungkapkan oleh Rusman dalam bukunya yang berjudul "Belajar dan Pembelajaran" menyatakan bahwa model pembelajaran dapat dijadikan pola pilihan, artinya para guru memilih model pembelajaran yang sesuai, efektif dan efesien untuk mencapai tujuan pembelajaran yang diharapkan.

\section{Peranan Model Pembelajaran Berbasis Multikultural Terhadap Pembentukan Interaksi Sosial Pada Pembelajaran IPS Siswa Di MTs Negeri 6 Cirebon Kabupaten Cirebon}

Peneliti telah melakukan observasi secara transparan tentunya diketahui oleh siswa dan guru MTs Negeri 6 Cirebon, peneliti telah melakukan kegiatan wawancara terhadap siswa dan guru, peneliti mewawancarai guru Ilmu Pengetahuan Sosial untuk mengambil hasil data yang akan dilakukan oleh peneliti, hal yang peneliti dapat adalah bahwasanya dalam proses belajar mengajar berlangsung khususnya pada mata pelajaran IPS sudah menggunakan model pembelajaran berbasis multikutural di kelas, siswa dan guru saling berinteraksi sosial di dalam pembelajaran maupun di luar jam pembelajaran, perbedaan tidak menjadi masalah untuk manusia saling berkomunikasi satu sama lain, karena manusia adalah makhluk sosial. Dengan adanya peranan model pembelajaran berbasis multikultural diharapkan dapat membentuk siswa saling menghargai (toleransi), empati, kerjasama, bersahabat dan bertanggungjawab.

\section{Toleransi}

Sikap dan tindakan yang menghargai suatu perbedaan agama, bahasa, suku, budaya, pendapat dan tindakan orang lain yang berbeda pendapat. 


\section{Empati}

Suatu perasaan dimana sesorang merasakan atau mengerti pengalaman orang lain, dan merasakanya sesaat seakan-akan anda sendiri yang merasakan. Contohnya jika teman kalian mendapatkan musibah, dan anda ikut merasakannya dan membantunya.

3. Kerjasama

Proses beregu atau berkelompok dimana anggota lainnya saling mendukung dan saling mengandalkan satu sama lain sehingga dapat tercapai hasil baik.

4. Bersahabat

Sikap atau tindakan yang memperlihatkan rasa senang, bicara, bergaul dan bekerjasama dengan orang lain baik di sekolah maupun di lingkungan masyarakat.

5. Bertanggungjawab

Sikap yang senantiasa menyelesaikan tugas dengan penuh kesadaran. Contohnya mengerjakan tugas dari guru dengan tepat, melaksanakan tugas piket dengan baik dan seorang ketua kelas melaksanakan tugas sebagai pemimpin kelas dengan baik.

\section{Faktor Pendukung Dan Penghambat Model Pembelajaran Berbasis} Multikultural Dalam Pembentukan Interaksi Sosial Pada Mata Pelajaran IPS Siswa di MTs Negeri 6 Cirebon Kabupaten Cirebon

Berdasarkan hasil observasi dan wawancara yang telah dilakukan, Hal ini dapat terlihat jika di MTs Negeri 6 Cirebon peranan model pembelajaran berbasis multikultural terdapat faktor pendorong dan penghambat pada proses pembelajaran khususnya pada mata pelajaran IPS, memiliki faktor pendorong dan penghambat dalam proses pembelajaran berlangsung, semuanya tidak berjalan dengan mulus. Sebagaimana yang diungkapkan oleh Sanjaya dalam buku (Rusman, 2017: 87) yang berjudul "Belajar dan Pembelajaran" beliau mengatakan bahwa mengajar dalam konteks standar pendidikan tidak hanya sekedar menyampaikan materi pelajaran, akan tetapi dimaknai sebagai proses mengatur lingkungan supaya siswa belajar. Pengaturan lingkungan adalah proses menciptakan lingkungan baik, seperti penataan lingkungan, penyediaan alat sumber pembelajaran, dan hal-hal lain yang memungkinkan siswa betah dan merasa senang belajar sehingga mereka dapat 
berkembang secara optimal sesuai dengan bakat, minat dan potensi yang dimilikinya.

\section{KESIMPULAN}

Berdasarkan pembahasan yang dilakukanpenelitisebelumnya di MTs Negeri 6 Cirebon Kabupaten Cirebon, maka dapat disimpulkan sebagai berikut:

1. Model pembelajaran berbasis multikultural di MTs Negeri 6 Cirebon Kabupaten Cirebon sudah terlaksana, dan beberapa guru sudah menerapkan menyesuaikan dengan materi yang di sampaikan pada saat proses pembelajaran IPS berlangsung.

2. Peranan model pembelajaran berbasis multikultural terhadap pembentukan interaksi sosial yang baik adalah tumbuhnya sikap toleransi, empati, bersahabat, kerjasama dan bertanggungjawab serta tidak adanya konflik dengan adanya perbedaan yang ada.

3. Faktor pendukung dan faktor penghambat model pembelajaran berbasis multikultural dalam pembentukan interaksi sosial siswa Kelas VII di MTs Negeri 6 Cirebon. Dari faktor pendukung memiliki beberapa faktor diantaranya ialah faktor Guru, Peseta didik, Sarana Prasarana dan Lingkungan. Dari Faktor penghambat adalah Guru, peserta didik, keluarga dan fasilitas (Sarana Prasarana).

\section{DAFTAR PUSTAKA}

Ary, Gunawan. 2010. Sosiologi Pendidikan. Jakarta: Rineka Cipta.

Creswell, J.W. 2010. Research Design: Pendekatan Kualitatif, Kuantitatif dan Mixed. Yogyakarta: Pustaka Pelajar.

Fitriyani, Anis. 2015. Pembelajaran IPS materi sejarah oleh guru berlatar belakang pendidikan bukan sarajana sejarah di SMP Negeri 2 Muntilan.

Komalasari, kokom. 2010. Pembelajaran Kontekstual Konsep dan Aplikasi. Bandung: Refika Aditama.

Kumala, Elma Azizah. 2018. penanaman nilai-nilai multikultural dalam pembelajaran pendidikan agama islam di SMP Negeri 1 Mertoyudan Kabupaten Magelan. https://dspace.uii.ac.id.

Mahfud, Choirul. 2010. Pendidikan Multikultural. Yogyakarta: Pustaka Pelajar.

Ngalimun. 2017. Kapita Selekta Pendidikan (Pembelajaran dan Bimbingan). Bantul Yogyakarta: Dua Satria Offset. 
Rusman. 2017. Belajar dan Pembelajaran. Jakarta : Prenadamedia Group.

Rusdiana, A. 2015 . Pendidikan Multikultural. Bandung : Pustaka Setia.

Sapriya. 2009. Konsep Dasar Ips. Bandung: Upi Press.

Setiadi,Elly M. 2007. Ilmu Sosial dan Budaya Dasar. Jakarta: Kencana Prenada Media Group.

Sugiyono. 2018. Metode Penelitian Kualitatif. Bandung: Alfabeta.

Sunarto, Kamanto. 2004.Pengantar Sosiologi. Jakarta : Fakultas Ekonomi Universitas Indonesia.

Suprijono, Agus. 2010. Cooperative Learning Teori \& Aplikasinya. Yogyakarta: Pustaka Pelajar.

Trianto. 2010. Model Pembelajaran Terpadu. Jakarta: Bumi Aksara.

Wulansari, Dewi. 2009. Sosiologi (Konsep dan Teori). Bandung : Refika Aditama. 